\title{
Perancangan sistem informasi inventarisasi aset berbasis web menggunakan metode waterfall
}

\author{
Maulia Usnaini ${ }^{1}$, Verdi Yasin ${ }^{2}$, Anton Zulkarnain Sianipar ${ }^{3}$ \\ Program Studi Sistem Informasi ${ }^{1}$, Program Studi Teknik Informatika ${ }^{2}$, Program Studi Teknik Komputer ${ }^{3}$, \\ Sekolah Tinggi Manajemen Informatika dan Komputer Jayakarta ${ }^{123}$ \\ mauliausnaini@gmail.com ${ }^{1}$,verdiyasin29@gmail.com ${ }^{2}$, antonz.jayakarta@gmail.com ${ }^{3}$
}

\begin{abstract}
ABSTRAK
Perkembangan ilmu pengetahuan terutama sistem infomasi dari tahun ke tahun sangat pesat dan dengan adanya kebutuhan penyelesaian pekerjaan semakin meningkat, sehingga sistem Inventaris Aset SDN Rawamangun 09 mengalami kemunduran kualitas laporan yang masih menggunakan sistem manual. Bagi sekolah dasar yang berorientasi pada bidang Pendidikan, aset ini di harapkan menjadi sarana dan prasarana sekolah yang dapat dipergunakan dan di jaga di masa yang akan datang. Selama ini untuk pengolahan data aset masih dilakukan secara manual oleh pengurus barang yaitu untuk pendataan barang yang dibeli dengan dana Bantuan Operasional Sekolah ( BOS) maupun bantuan Aset yang di peroleh dari Dinas Pendidikan Provinsi DKI Jakarta. Dimulai dengan mencatat Kartu Inventaris Barang ( KIB ) lalu di salin di komputer, pada saat arsip aset di sekolah di perlukan sewaktu - waktu mengakibatkan lamanya waktu pencarian dan kurang lengkap nya data yang disajikan. Untuk menanggulangi permasalahan dan memenuhi serta mencapai efisiensi data pada SDN Rawamangun 09. Oleh karena itu penulisan sistem informasi inventaris aset berbasis web ini dapat memudahkan sistem kerja di mulai dari penginputan melalui web sampai dengan hasil laporan dalam bentuk pdf , selain data tercatat dengan rapih dan efisien kekeliruan pencatatan inventaris dapat berkurang . Kata kunci: Maksimum 5 kata kunci dipisahkan dengan tanda koma, harus spesifik, hindari singkatan (sesuai dengan ruang lingkup artikel dan jurnal)..
\end{abstract}

Kata Kunci- Perancangan sistem informasi Inventaris Aset, SDN Rawamangun 09

Abstract: Currently the internet has become one of the cheapest communication infrastructure and has a wide and unlimited acceptance range, so the internet is often used as an alternative medium for running a business or business. For elementary schools that are oriented towards the field of education, these assets are expected to become school facilities and infrastructure that can be used and protected in the future. So far, asset data processing is still done manually by the goods manager, namely for data collection of goods purchased with School Operational Assistance (BOS) funds and asset assistance obtained from the DKI Jakarta Provincial Education Office. Starting with recording the Goods Inventory Card (KIB) and then copying it on the computer, when the asset archive at school is needed at any time it results in a long search time and incomplete data presented.To overcome problems and fulfill and achieve data efficiency at SDN Rawamangun 09. Therefore, writing a web-based asset inventory information system can facilitate the work system starting from input via the web to reporting results in pdfformat, in addition to the data being recorded neatly and efficiently.

Keywords-Asset inventory information system design, SDN Rawamangun 09 rors in recording inventory can be reduced.

\section{PENDAHULUAN}

Penggunaan Sistem Informasi saat ini sudah menjadi keharusan di berbagai instansi. Sistem komputerisasi merupakan cara untuk meningkatakan informasi yang akurat, relevan dan tepat waktu yang dapat digunakan sebagai pertimbagan dalam pengambilan keputusan. Peran serta teknologi menjadikan pengolahan informasi menjadi semakin mudah karena pengolahan sangatbdi perlukan agar informasi yang di hasilkan dapat bermanfaat bagi penggunanya.

Inventarisasi merupakan kegiatan atau tindakan yang digunakan untuk mencatat, menghitung aset yang ada pada instansi , pengelolaan aset dan pelaporan aset . dengan kata lain setiap unit kerja diwajibkan untuk 
DOI: $10.52362 / j m i j a y a k a r t a . v 1 i 1.415$

mekakukan inventaris aset baik sebagai laporan penggunaan finansial pada suatu instansi juga merupakan tolak ukur kebutuhan sarana dan prasarana pada suatu instansi terutama pada bidang pendidikan .

Bagi sekolah dasar yang berorientasi pada bidang Pendidikan, aset ini di harapkan menjadi sarana dan prasarana sekolah yang dapat dipergunakan dan di jaga di masa yang akan datang. Selama ini untuk pengolahan data aset masih dilakukan secara manual oleh pengurus barang yaitu untuk pendataan barang yangmdibeli dengan dana Bantuan Operasional Sekolah (BOS) maupun bantuan Aset yang di peroleh dari Dinas Pendidikan Provinsi DKI Jakarta . dimulai dengan mencatat Kartu Inventaris Barang (KIB) lalu di salin di komputer , pada saat arsip aset di sekolah di perlukan sewaktu - waktu mengakibatkan lamanya waktu pencarian dan kurang lengkap nya data yang disajikan.

Untuk menanggulangi permasalahan dan memenuhi serta mencapai efisiensi data pada SDN Rawamangun 09. Oleh karena itu penulisan sistem yang akan dibangun di harapkan dapat mempermudah pekerjaan di SDN Rawamangun 09 dalam mengelola dan mengontrol aset sekolah maka akan di lakukan penelitian "Perancangan Sistem Informasi Inventarisasi Aset Berbasis WEB Pada SDN Rawamangun 09”.

\section{METODE DAN MATERI}

\section{A. MATERI}

Perancangan sistem adalah proses pengembangan spesifikasi sistem baru bedasarkan hasil rekomendasi analisis sistem. Dalam tahap perancangan.tim kerja desain harus merancang spesifikasi yang dibutuhkan dalam berbagai kertas kerja. Kertas kerja itu harus memuat berbagai uraian mengenai input, proses, dan output dari sistem yang di usulkan. [1]

\subsection{Pengertian Perancangan Sistem}

Suatu sistem pada dasarnya adalah sekelompok unsur yang erat hubunganya satu dengan yang lain, yang berfungsi Bersama - sama untuk mencapai tujuan tertentu . secara sederhana, suatu sistem dapat di artikan sebagai suatu kumpulan atau himpunan dari unsur, komponen, atau vaiabel yang terorganisir, saling berinteraksi, saling tergantung satu sama lain, dan terpadu [2]

\subsection{Pengertian Inventaris Aset}

inventaris barang adalah kegiatan pengelolaan persediaan segala sesuatu yang memiliki nilai finansial, berlaku untuk perorangan, perusahaan dan pemerintahan. Aset merupakan sesuatu yang bernilai ekonomis dari pemamfaat/pengoprasian yang menghasilkan pendapatan dan siklus umurnya Panjang.

Sebagai contoh : Tanah, peralatan dan mesin, bangunan, jalan, irigasi, dan jaringan , dan pencatatan data barang yang masih dalam tahap konstruksi (pembuatan).

Kebutuhan sarana dan prasarana yang di butuhkan dalam kegiatan pekerjaan tidak menutup kemungkinan perusahan melakukan kegiatan inventaris aset dalam kurun waktu paling sedikit 1 tahun sekali

\subsection{Pengertian website}

Website atau situs dapat di artikan sebagai kumpulan halaman - halaman yang di gunakan untuk menampilkan informasi teks, gambar diam atau gerak, animasi , suara , atau gabungan dari semuanya, baik yang bersifat statis maupun dinamis yang berbentuk satu rangkaian bangunan yang saling terkait, yang masing - masing dihubungkan dari jaringan jarigan halaman. Hubungan antara satu halaman web dengan yang lainya di sebut hyperlink, dengan teks yang di jadikan media penghubung disebut hypertext [3]

\subsection{Metode Waterfall}

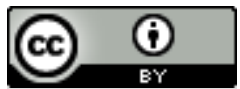

Ciptaan disebarluaskan di bawah Lisensi Creative Commons Atribusi 4.0 Internasional. http://journal.stmikjayakarta.ac.id/index.php/JMIJayakarta 
DOI: $10.52362 / j m i j a y a k a r t a . v 1 i 1.415$

SLDC (Systems Development Life Cycle) merupakan point yang sangat vital, krusial, dan keputusan didalam Software development pada sebuah proyek . sukses atau tidaknya sebuah proyek sudah bisa diprediksi pada saat manajer proyek menentukan model SLDC mana yang akan diambil. Model Waterfall adalah model pertama digunakan dan umum digunakan dan umum digunakan oleh project-project pemerintahan dan perusahaan besar. Model ini juga menekankan pentingnya dokumentasi sehingga model ini cocok untuk proyek yang mengedepankan kualitas. [4]

\section{B. METODE}

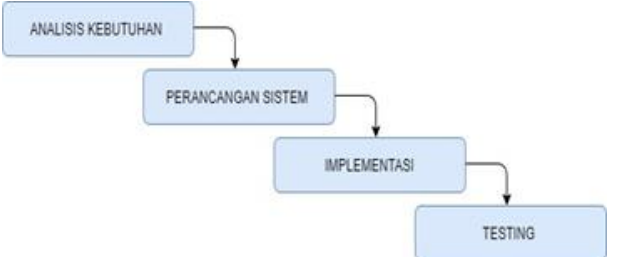

Gambar 2.1 Metode Waterfall

Metode Waterfall ini mempunyai Tahapan seperti dibawah ini:

1. Analisa Kebutuhan

Kendala dan permintaan user kumpulkan untuk melakukan perancangan sistem agar sistem bisa di buat sesuai dengan keinginan,.

2. Perancangan Sistem

Tahap dimana penerapan terhadap analisa kebutuhan di rancang menggunakan perangkat keras dan perangkat lunak

3. Implementasi

Penerapan dan pelaksanan gabungan dari sistem yang sudah dibangun pada tahap sebelumnya, diterapkan dalam bentuk implementasi dari awal unit program menjadi satu kesatuan .

4. $\quad$ Testing

Pegujian program, digabungkan, dan diverivikasi untuk melihat apakah sistem siap untuk memenuhi kebutuhan yang di inginkan.

\section{PEMBAHASAN DAN HASIL}

\subsection{Analisis Kebutuhan}

Analisis kebutuhan sistem didapat dari observasi dan wawancara langsung kepada Kepala Sekolah SDN Rawamangun 09 mengenai apasaja yang dibutuhkan dalam pembuatan perancangan sistem informasi Inventaris aset tersebut

\subsection{Perancangan Sistem}

Perancangan sistem dilakukan dengan menggunakan UML (Unified Modeling Language) yang tahapan didalamnya berisi Use Case, Activity Diagram, Class Diagram, Sequance Diagram , sedagkan untuk pengimplementasian dilakukan dengan bahasa pemogram PHP yang di bantu dengan Xampp Webserver.

\section{3. implementasi dan Testing}

Pengujian melalui oleh black box yaitu pengujian proses sistem berjalan yang menitikberatkan pada fungsionalitas sistem terhadap keinginan pengguna, Studi literatur , Studi Lapangan , Studi Pustaka, dan SWOT yang merupakan metode analisis perencanaan strategis yang digunakan untuk mengevaluasi lingkungan lokasi penelitian dengan tujuan tertentu. 
DOI: $10.52362 / j m i j a y a k a r t a . v 1 i 1.415$

Tabel 3.1 Hasil Analisis Kebutuhan

\begin{tabular}{|l|l|}
\hline Activity & Functional Requirement \\
\hline $\begin{array}{l}\text { Mengelola } \\
\text { data inventaris }\end{array}$ & $\begin{array}{l}\text { Sistem yang dirancang harus } \\
\text { dapat menampilkan, mengubah, } \\
\text { dan menambah data invetaris }\end{array}$ \\
\hline $\begin{array}{l}\text { Mengelola } \\
\text { stok barang }\end{array}$ & $\begin{array}{l}\text { Sistem yang dirancang harus } \\
\text { dapat menampilkan dan } \\
\text { menambah stok barang }\end{array}$ \\
\hline $\begin{array}{l}\text { Mengelola } \\
\text { data barang } \\
\text { masuk }\end{array}$ & $\begin{array}{l}\text { Sistem yang dirancang harus } \\
\text { dapat menampilkan dan } \\
\text { menambah barang masuk }\end{array}$ \\
\hline $\begin{array}{l}\text { Mengelola } \\
\text { data barang } \\
\text { keluar }\end{array}$ & $\begin{array}{l}\text { Sistem yang dirancang harus } \\
\text { dapat menampilkan dan } \\
\text { menambah barang keluar }\end{array}$ \\
\hline $\begin{array}{l}\text { Mengelola } \\
\text { data pemakai }\end{array}$ & $\begin{array}{l}\text { Sistem yang dirancang harus } \\
\text { dapat menampilkan, merubah, } \\
\text { dan menghapus data pelanggan }\end{array}$ \\
\hline
\end{tabular}

Bedasarkan kebutuhan fungsionaliats, maka disimpulkan sistem informasi ini membutuhkan hardware dan software, seperti di bawah ini :

Kebutuhan Hardware :

1. Processor Intel Braswell N3060

2. Random Acces Memory 2GB/4 GB DDR3L

3. Hard disk 500 GB HDD SATA

Kebutuhan minimum pada software :

1. Komputer Terinstall Windows 1064 Bit

2. Xampp Versi 5.6.28

3. Database MySQL 4.5.1

Analisis Usecase diagram :

Use case merupakan sarana atau aktivitas yang disiapkan oleh sistem sebagai unit-unit yang saling bertukar pesan antar unit atau aktor biasanya menggunakan kata kerja di awal frase.[5]

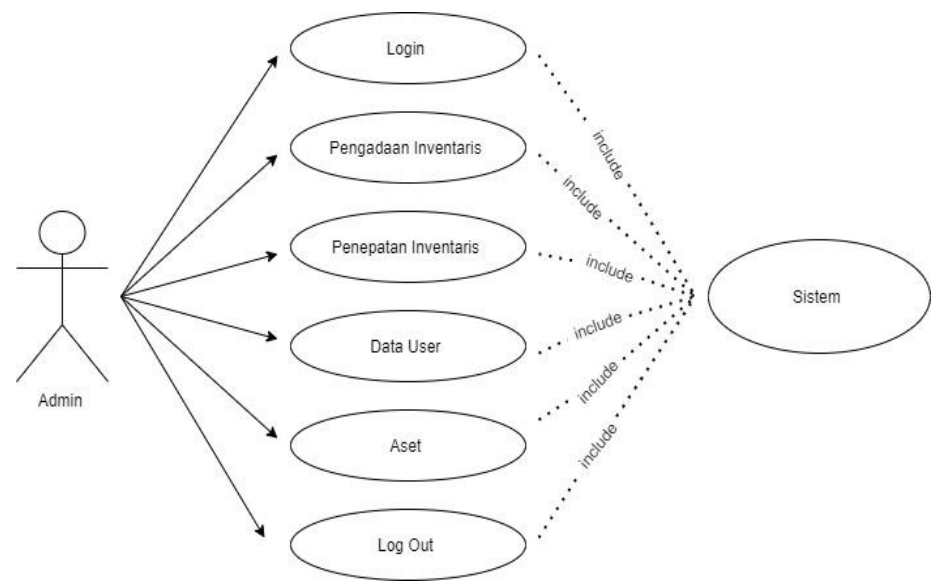

Gambar 3.1 Usercase Sistem inventaris aset

Analisis Activity Diagram : 
DOI: $10.52362 / j m i j a y a k a r t a . v 1 i 1.415$

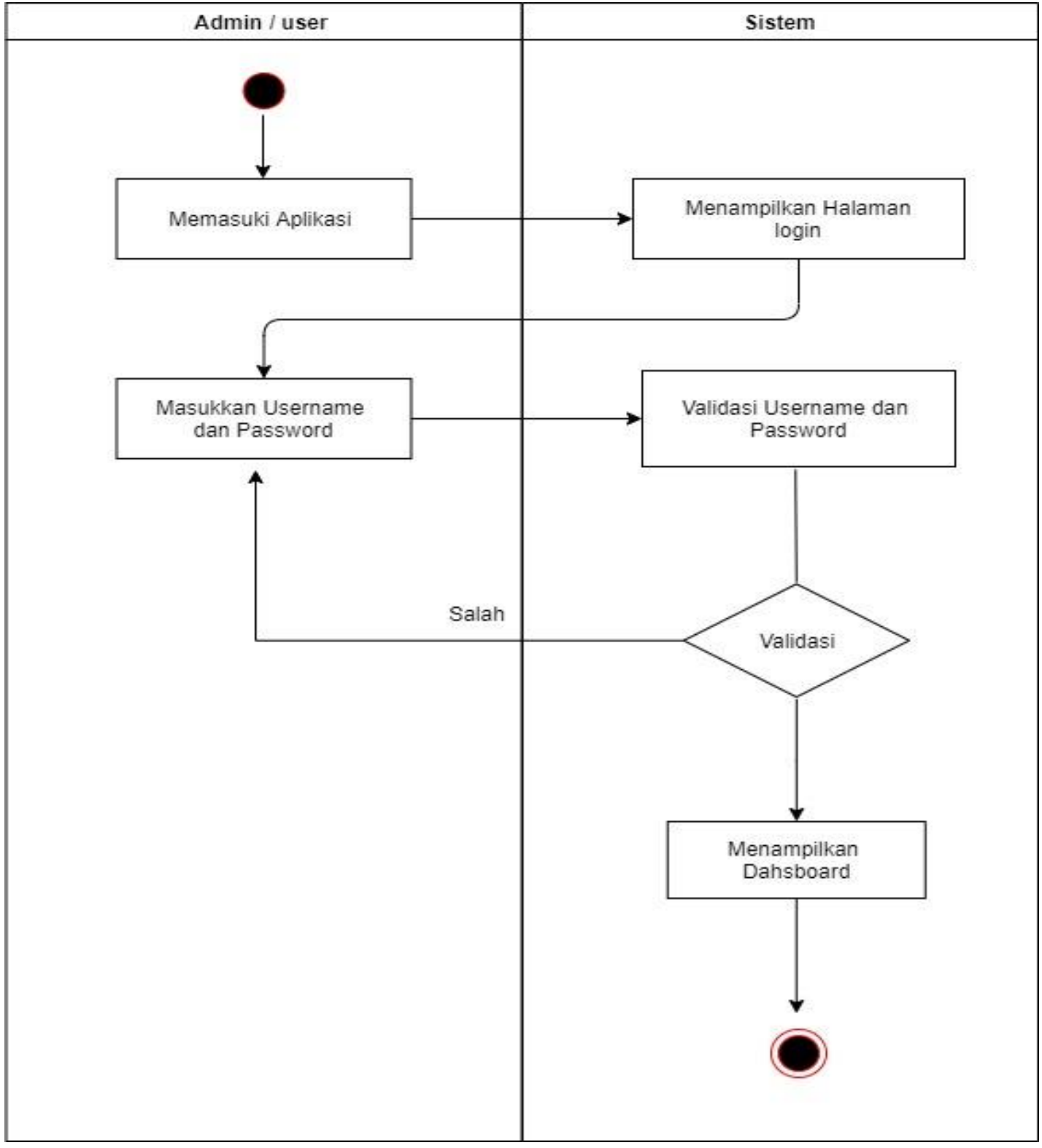

Gambar 3.2 Activity Diagram Menu Dashboard

Analisis database sistem menggunakan MY SQL Server :

Tabel 3.2 Database User

\begin{tabular}{|c|l|l|l|}
\hline No & \multicolumn{1}{|c|}{ Nama Field } & \multicolumn{1}{|c|}{ Tipe Data } & \multicolumn{1}{|c|}{ Keterangan } \\
\hline 1 & user_Id & \multicolumn{1}{|c|}{ Int () } & id \\
\hline 2 & user_name & Varchar(10) & Usename \\
\hline 3 & Passwod & Varchar(10) & Password \\
\hline 4 & Level & Varchar (5) & admin \\
\hline 5 & Kode_Cabang & Varchar (3) & kode cabang \\
\hline
\end{tabular}


DOI: $10.52362 / j m i j a y a k a r t a . v 1 i 1.415$

Tabel 3.2 Database Pengadaan

\begin{tabular}{|r|l|l|l|}
\hline No & \multicolumn{1}{|c|}{ Nama Field } & \multicolumn{1}{c|}{ Tipe Data } & \multicolumn{1}{c|}{ Keterangan } \\
\hline 1 & id_Pengadaan & Int (11) & id \\
\hline 2 & Kode_pengadaan & varchar (18) & kode pengadaan \\
\hline 3 & Kode_barang & varchar (7) & kode barang \\
\hline 4 & Kode_cabang & varchar (3) & kode cabang \\
\hline 5 & Kode_Supplier & varchar (5) & kode Supplier \\
\hline 6 & no_Polisi & varchar (25) & no Polisi \\
\hline 7 & no_BPKB & varchar(15) & no BPKB \\
\hline 8 & no_Sertifikat & varchar(60) & no Sertifikat \\
\hline 9 & no_Faktur & varchar(15) & no Faktur \\
\hline 10 & Tgl_beli & date & tgl beli \\
\hline 11 & harga_beli & decimal(18,0) & harga beli \\
\hline 12 & jumlah & Int (11) & jumlah jumlah \\
\hline 13 & sisa_jumlah & Int (11) & sisa jumlah \\
\hline 14 & user_Posting & Varchar (11) & user Posting \\
\hline 15 & luas & Varchar (15) & luas luas \\
\hline
\end{tabular}

Tabel 3.2 Database Penempatan Barang

\begin{tabular}{|r|l|l|l|}
\hline No & \multicolumn{1}{|c|}{ Nama Field } & \multicolumn{1}{|c|}{ Tipe Data } & \multicolumn{1}{c|}{ Keterangan } \\
\hline 1 & kd_ruangan & varchar (6) & Kode Ruangan \\
\hline 2 & nm_ruangan & varchar (30) & Nama Ruangan \\
\hline 3 & keterangan & varchar (15) & Keterangan \\
\hline 4 & user_posting & varchar (11) & User yang memposting \\
\hline 5 & tgl_posting & date & Tanggal Postingan \\
\hline
\end{tabular}

Implementasi :

User dapat masuk ke dashboard menggunakan akses username dan password di halaman login, seperti yang terlihat pada gambar dibawah ini 
DOI: $10.52362 / j m i j a y a k a r t a . v 1 i 1.415$

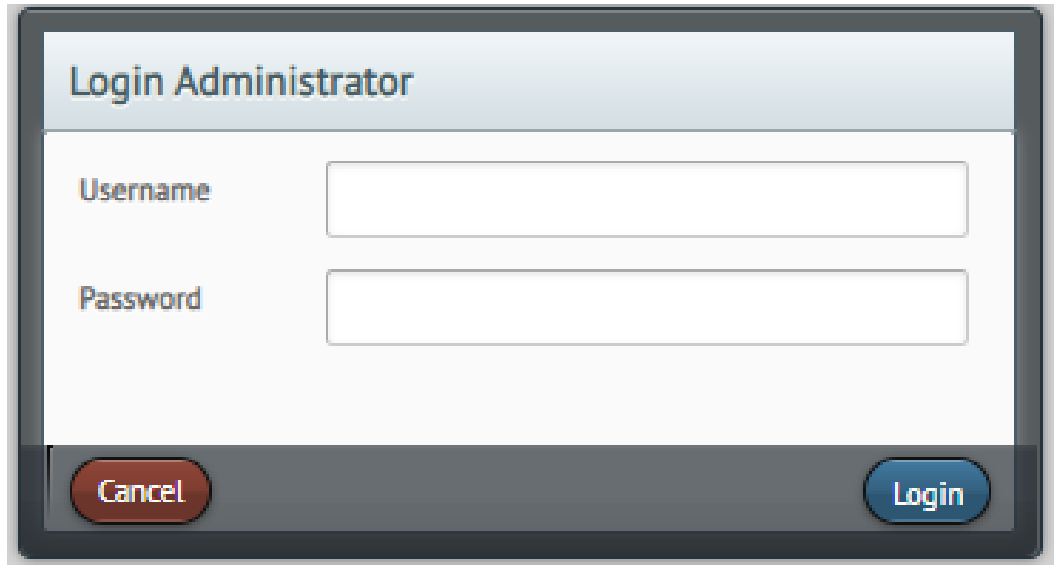

Gambar 3.3 Halaman Login

Setelah mengisi username dan password pengguna, selanjutnya aplikasi menampilkan tampilan

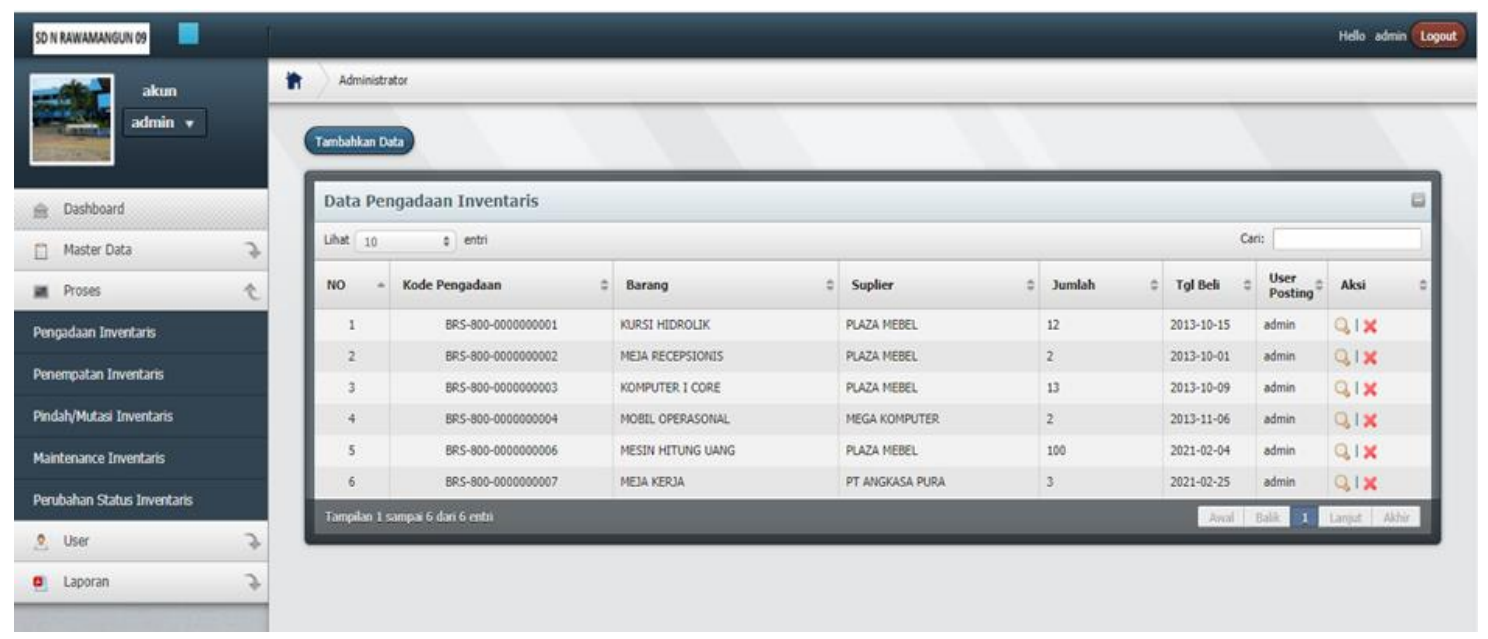

Gambar 3.4 Pengadaan Inventaris

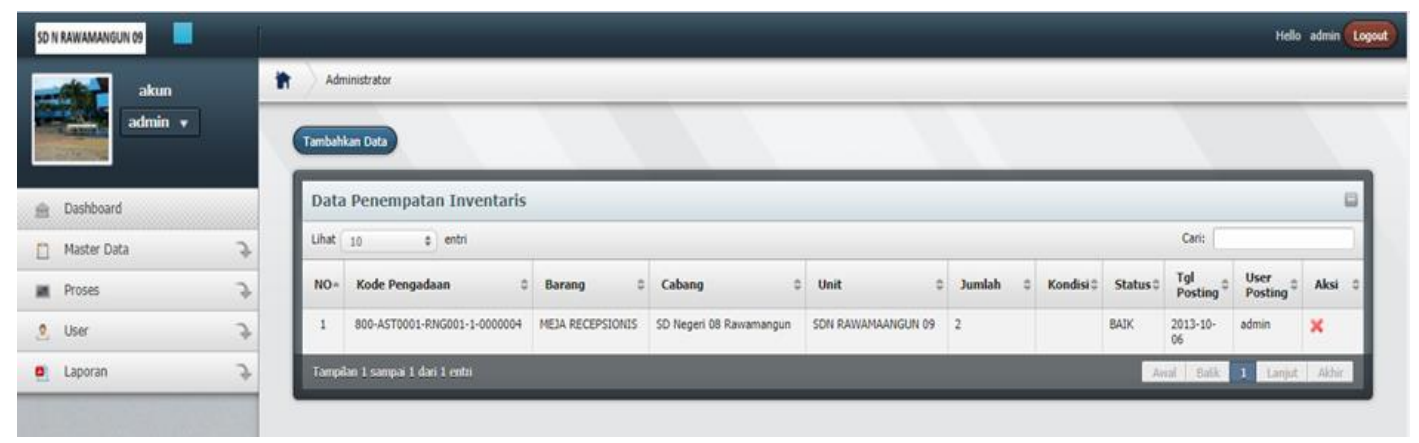

Gambar 3.5 Penempatan Inventaris

Black box testing dilakukan dengan model uat dengan tampilan seperti dibawah ini :

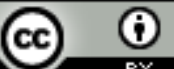

Ciptaan disebarluaskan di bawah Lisensi Creative Commons Atribusi 4.0 Internasional. http://journal.stmikjayakarta.ac.id/index.php/JMIJayakarta 
DOI: $10.52362 / j m i j a y a k a r t a . v 1 i 1.415$

Tabel 4 .9 UAT 1

\begin{tabular}{|l|l|}
\hline \multicolumn{2}{|c|}{ DOKUMENTASI USER ACCEPTANCE TEST } \\
\hline UAT (USER ACCEPTANCE TEST) 1 \\
\hline Penguji 1 & : Dosen Pembimbing \\
\hline Nama Penguji & : Dr. Verdi Yasin, S.Kom, M.Kom \\
\hline
\end{tabular}

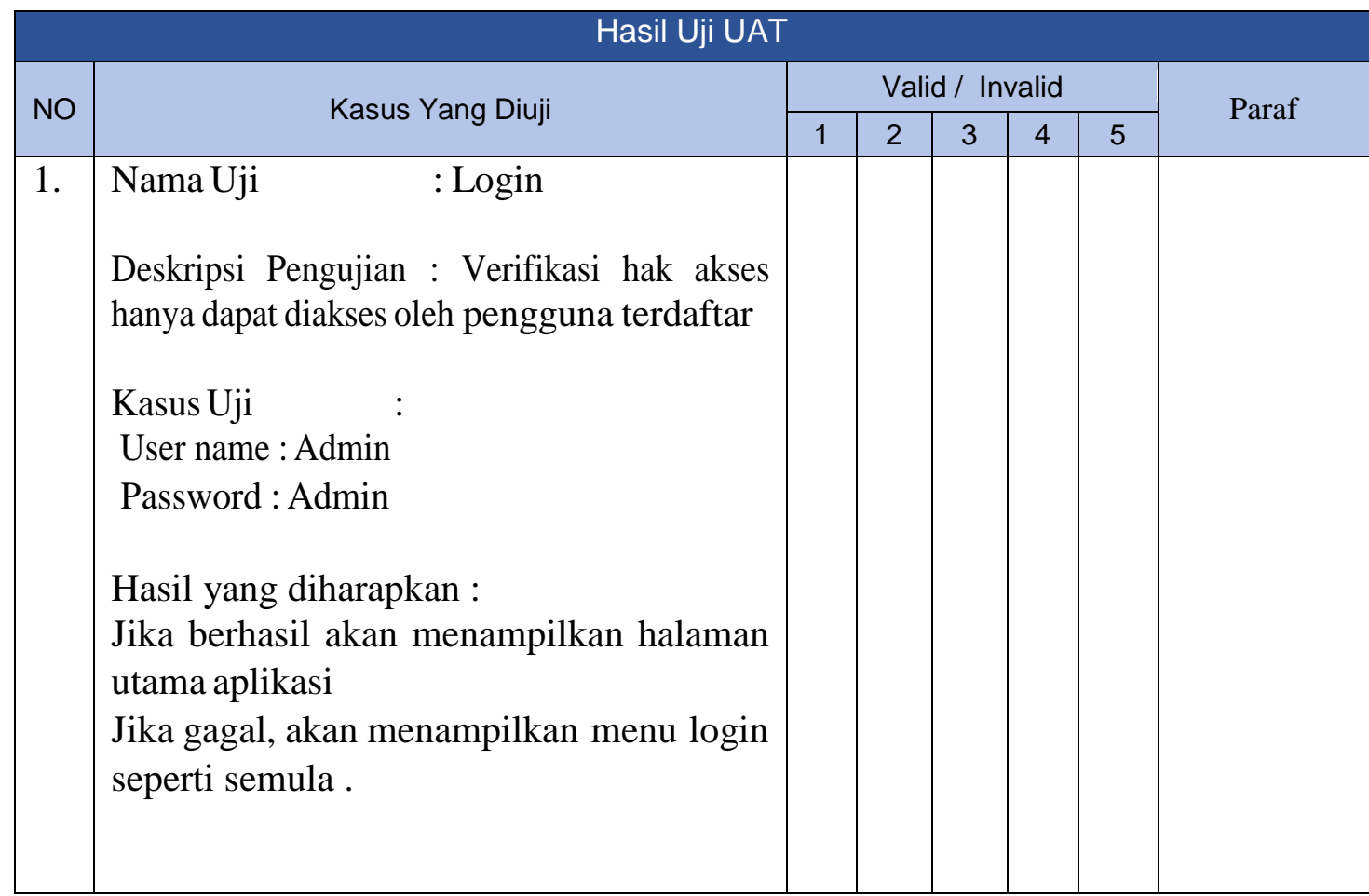


DOI: $10.52362 / j m i j a y a k a r t a . v 1 i 1.415$

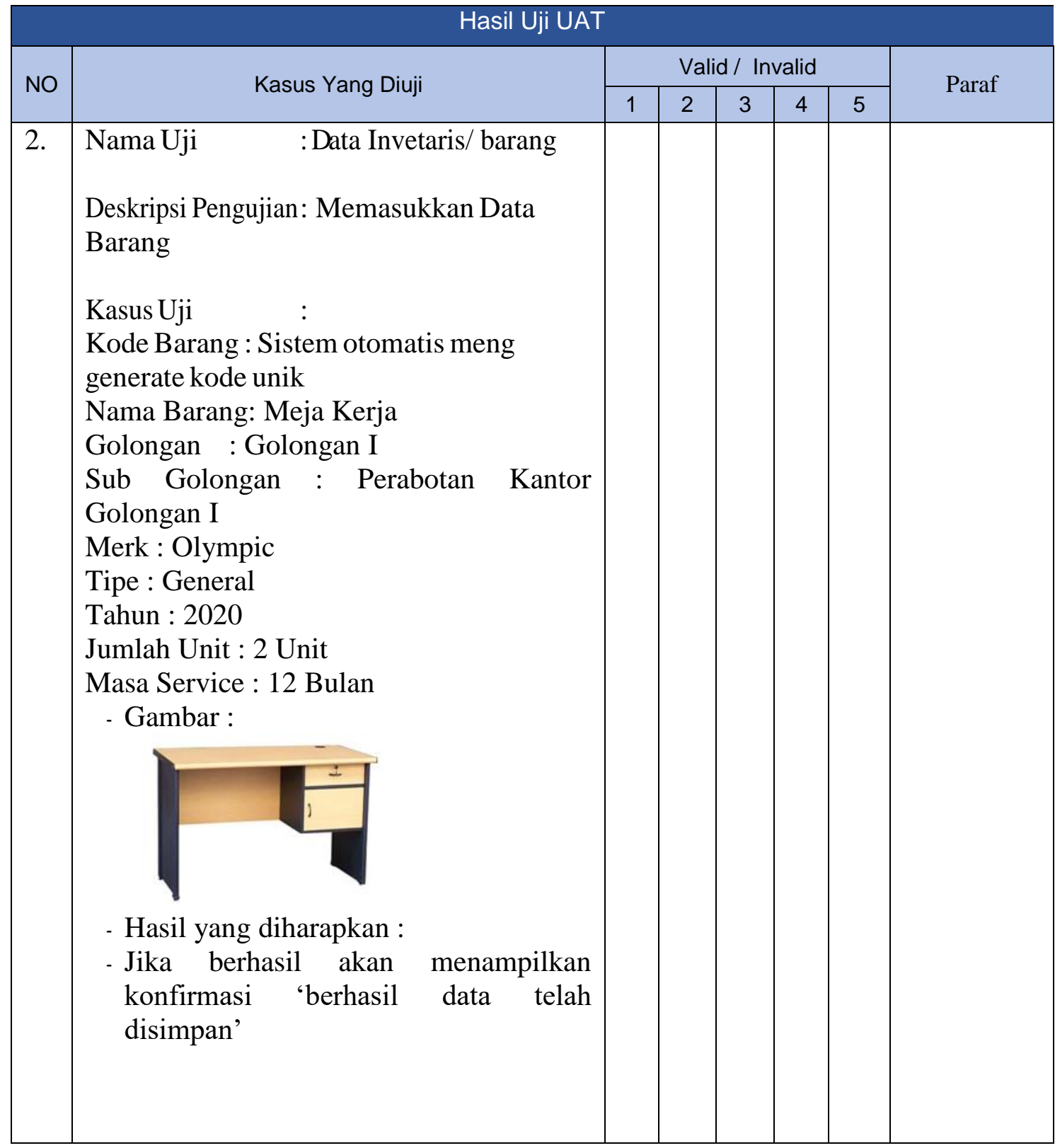


DOI: $10.52362 / j m i j a y a k a r t a . v 1 i 1.415$

\begin{tabular}{|c|c|c|c|c|c|c|c|}
\hline \multirow{2}{*}{ NO } & \multirow{2}{*}{ Kasus Yang Diuji } & \multicolumn{5}{|c|}{ Valid / Invalid } & \multirow{2}{*}{ Paraf } \\
\hline & & 1 & 2 & 3 & 4 & 5 & \\
\hline 3. & $\begin{array}{l}\text { Nama Uji : Jenis Inventaris } \\
\text { Deskripsi Pengujian: memasukkan Data } \\
\text { Jenis Inventaris } \\
\text { Kasus Uji : } \\
\text { Kode : Sistem otomatis meng-generate } \\
\text { kode unik } \\
\text { Jenis Aset : Aset Tetap } \\
\text { Keterangan : Meja Kerja } \\
\text { Hasil yang diharapkan : } \\
\text { Jika berhasil akan menampilkan } \\
\text { konfirmasi 'berhasil data telah disimpan' }\end{array}$ & & & & & & \\
\hline 4. & $\begin{array}{l}\text { Nama Uji : Golongan Inventaris } \\
\text { Deskripsi Pengujian : memasukkan } \\
\quad \text { Data Golongan Inventaris Barang } \\
\text { Kasus Uji : } \\
\text { Kode : Sistem otomatis meng-generate } \\
\text { kode unik } \\
\text { Nama Golongan : Golongan } 1 \\
\text { Keterangan : kayu } \\
\text { Penyusutan : } 5 \% \\
\text { Masa mamfaat : } 10 \text { Tahun } \\
\text { Hasil yang diharapkan : } \\
\text { Jika berhasil akan menampilkan } \\
\text { konfirmasi ‘berhasil data telah disimpan’ }\end{array}$ & & & & & & \\
\hline
\end{tabular}


DOI: $10.52362 / j m i j a y a k a r t a . v 1 i 1.415$

\begin{tabular}{|c|c|c|c|c|c|c|c|}
\hline \multirow[b]{2}{*}{ NO } & \multirow[b]{2}{*}{ Kasus Yang Diuji } & \multicolumn{5}{|c|}{ Valid / Invalid } & \multirow[b]{2}{*}{ Paraf } \\
\hline & & 1 & 2 & 3 & 4 & 5 & \\
\hline 5. & $\begin{array}{l}\text { Nama Uji : Sub Golongan Inventaris } \\
\text { Deskripsi Pengujian : Verifikasi Sub } \\
\quad \text { Golongan } \\
\text { Kasus Uji : } \\
\text { Kode : Sistem otomatis meng-generate } \\
\text { kode unik } \\
\text { Golongan : Golongan } 2 \\
\text { Nama Sub Golongan : Meja Kerja } \\
\text { Hasil yang diharapkan : } \\
\text { Jika berhasil akan menampilkan } \\
\text { konfirmasi 'berhasil data telah disimpan' }\end{array}$ & & & & & & \\
\hline 6. & $\begin{array}{l}\text { Nama Uji : Data Unit Kerja } \\
\text { Deskripsi Pengujian: Verifikasi Data Unit } \\
\text { Kerja } \\
\text { Kasus Uji } \quad: \text { : Sistem otomatis meng- } \\
\text { Kode Unit generate kode unik } \\
\text { Nama Unit : SDN RAWAMANGUN } 09 \\
\text { Keterangan : Ruang Guru } \\
\text { Hasil yang diharapkan : } \\
\text { Jika berhasil akan menampilkan } \\
\text { konfirmasi 'berhasil data telah disimpan' }\end{array}$ & & & & & & \\
\hline
\end{tabular}


DOI: $10.52362 / j m i j a y a k a r t a . v 1 i 1.415$

\begin{tabular}{|c|c|c|c|c|c|c|c|}
\hline \multirow[b]{2}{*}{ NO } & \multirow{2}{*}{ Kasus Yang Diuji } & \multicolumn{5}{|c|}{ Valid / Invalid } & \multirow[b]{2}{*}{ Paraf } \\
\hline & & 1 & 2 & 3 & 4 & 5 & \\
\hline 5. & $\begin{array}{l}\text { Nama Uji : Data Ruangan } \\
\text { Deskripsi Pengujian: Verifikasi Data Data } \\
\text { Ruangan } \\
\text { Kasus Uji : } \\
\text { Kode Unit : Sistem otomatis meng- } \\
\text { generate kode unik } \\
\text { Nama Ruangan : Ruang Guru } \\
\text { Keterangan : Lantai I } \\
\text { Hasil yang diharapkan : } \\
\text { Jika berhasil akan menampilkan } \\
\text { konfirmasi 'berhasil data telah disimpan' }\end{array}$ & & & & & & \\
\hline 6. & $\begin{array}{l}\text { Nama Uji : Data Supplier } \\
\text { Deskripsi Pengujian: Verifikasi Data Data } \\
\text { Ruangan } \\
\text { Kasus Uji : } \\
\text { Kode Unit : Sistem otomatis meng- } \\
\text { generate kode unik } \\
\text { Nama Ruangan : Ruang Guru } \\
\text { Keterangan : Lantai I } \\
\text { Hasil yang diharapkan : } \\
\text { Jika berhasil akan menampilkan } \\
\text { konfirmasi 'berhasil data telah disimpan'. }\end{array}$ & & & & & & \\
\hline
\end{tabular}


DOI: $10.52362 / j m i j a y a k a r t a . v 1 i 1.415$

\begin{tabular}{|c|c|c|c|c|c|c|c|}
\hline \multirow[b]{2}{*}{ NO } & \multirow[b]{2}{*}{ Kasus Yang Diuji } & \multicolumn{5}{|c|}{ Valid / Invalid } & \multirow[b]{2}{*}{ Paraf } \\
\hline & & 1 & 2 & 3 & 4 & 5 & \\
\hline 7. & 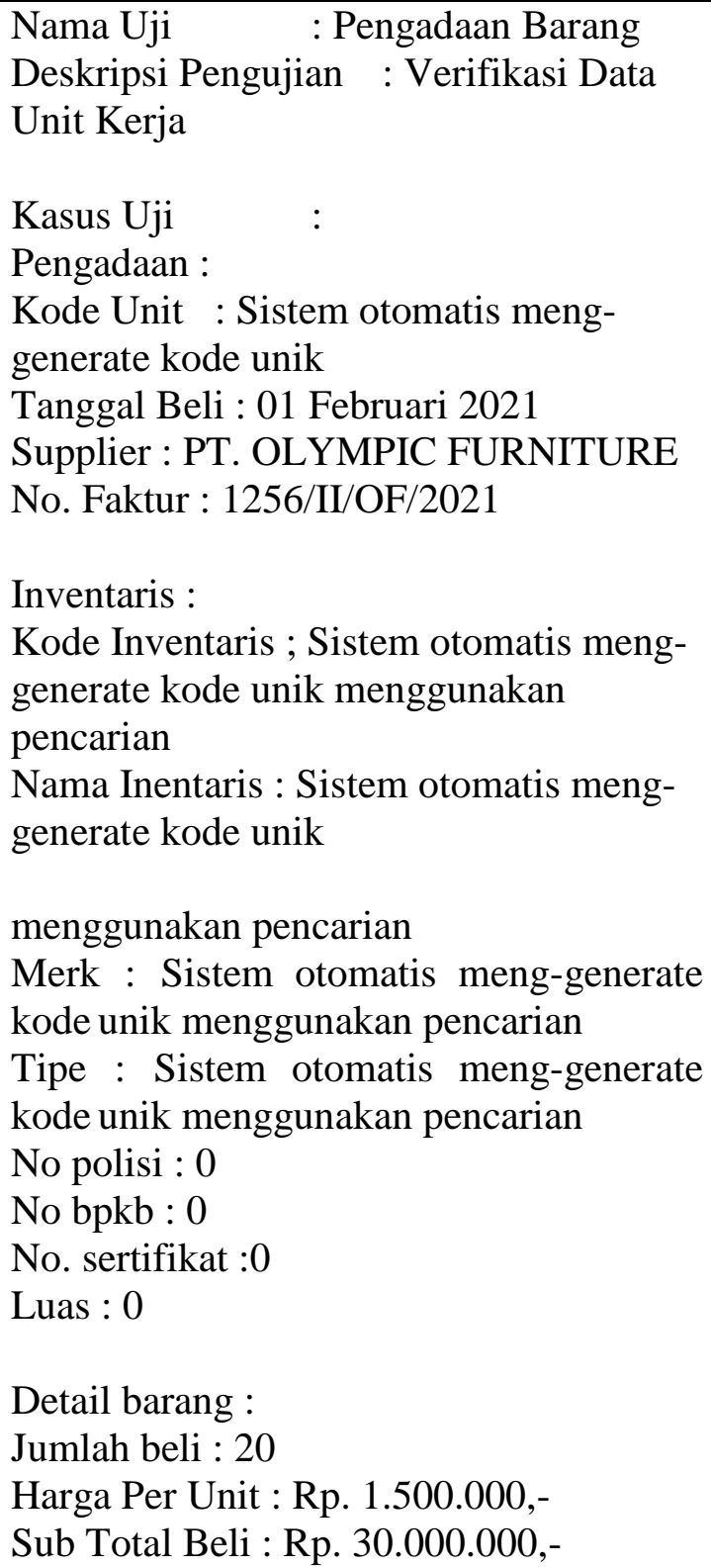 & & & & & & \\
\hline
\end{tabular}


DOI: $10.52362 / j m i j a y a k a r t a . v 1 i 1.415$

\begin{tabular}{|c|c|c|c|c|c|c|c|}
\hline \multirow[b]{2}{*}{ NO } & \multirow[b]{2}{*}{ Kasus Yang Diuji } & \multicolumn{5}{|c|}{ Valid / Invalid } & \multirow[b]{2}{*}{ Paraf } \\
\hline & & 1 & 2 & 3 & 4 & 5 & \\
\hline & $\begin{array}{l}\text { Hasil yang diharapkan : } \\
\text { Jika berhasil akan menampilkan } \\
\text { konfirmasi 'data barang berhasil } \\
\text { disimpan' dan menampilkan tabel barang } \\
\text { dimana data yang diinput sudah masuk } \\
\text { dalam tabel barang tersebut. }\end{array}$ & & & & & & \\
\hline 9. & $\begin{array}{l}\text { Nama Uji : Penempatan } \\
\text { Inventaris } \\
\text { Deskripsi Pengujian : Verifikasi } \\
\text { Penempatan Inventaris } \\
\text { Kasus Uji : } \\
\text { Kode Inventaris : Sistem otomatis } \\
\text { meng-generate kode unik } \\
\text { menggunakan pencarian } \\
\text { Nama Inventaris : Sistem otomatis } \\
\text { meng-generate kode unik } \\
\text { menggunakan pencarian } \\
\text { Kode Pengadaan : Sistem otomatis meng- } \\
\text { generate kode unik menggunakan } \\
\text { pencarianmenggunakan pencarian } \\
\text { Hasil yang diharapkan : } \\
\text { Jika berhasil akan menampilkan } \\
\text { konfirmasi 'data barang berhasil } \\
\text { disimpan' dan menampilkan tabel } \\
\text { barang dimana data yang diinput } \\
\text { sudah masuk dalam tabel barang }\end{array}$ & & & & & & \\
\hline
\end{tabular}


DOI: $10.52362 / j m i j a y a k a r t a . v 1 i 1.415$

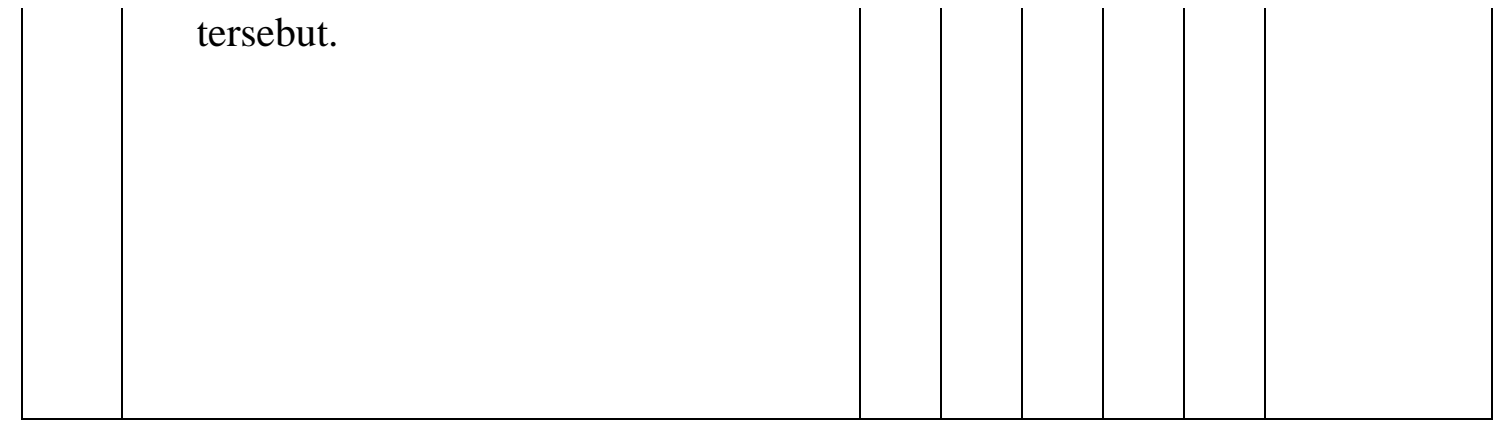

\begin{tabular}{|c|c|c|c|c|c|c|c|}
\hline \multirow[b]{2}{*}{ NO } & \multirow[b]{2}{*}{ Kasus Yang Diuji } & \multicolumn{5}{|c|}{ Valid / Invalid } & \multirow{2}{*}{ Paraf } \\
\hline & & 1 & 2 & 3 & 4 & 5 & \\
\hline 10. & $\begin{array}{l}\text { Nama Uji : Pindah /Mutasi } \\
\text { Inventari } \\
\text { Deskripsi Pengujian: Verifikasi Penempatan } \\
\text { Inventaris } \\
\text { Kasus Uji : } \\
\text { Data Inventaris : } \\
\text { Kode Barang : Sistem otomatis meng- } \\
\text { generate kode unik menggunakan } \\
\text { pencarian } \\
\text { Nama Barang: Sistem otomatis meng- } \\
\text { generate kode unik menggunakan } \\
\text { pencarian } \\
\text { Merk : Sistem otomatis meng-generate } \\
\text { kode unik menggunakan pencarian } \\
\text { Tipe : Sistem otomatis meng-generate } \\
\text { kode unik menggunakan pencarian } \\
\text { Tanggal Pengadaan : Sistem otomatis } \\
\text { meng-generate kode unik menggunakan } \\
\text { pencarian } \\
\text { Ruang Aset : } \\
\text { Ruang : Sistem otomatis meng-generate } \\
\text { kode unik menggunakan pencarian } \\
\text { Unit : Sistem otomatis meng-generate } \\
\text { kode unik menggunakan pencarian } \\
\text { Kode Inventaris : Sistem otomatis meng- }\end{array}$ & & & & & & \\
\hline
\end{tabular}


DOI: $10.52362 / j m i j a y a k a r t a . v 1 i 1.415$

$\left|\begin{array}{l}\text { generate kode unik menggunakan } \\ \text { pencarian. } \\ \text { Hasil yang diharapkan : } \\ \text { Jika berhasil akan menampilkan } \\ \text { konfirmasi data barang berhasil } \\ \text { disimpan' dan menampilkan tabel barang } \\ \text { dimana data yang diinput sudah masuk } \\ \text { dalam tabel barang tersebut. }\end{array}\right|+|+|+|+|+\mid$

\begin{tabular}{|c|c|c|c|c|c|c|c|}
\hline \multirow{2}{*}{ NO } & \multirow{2}{*}{ Kasus Yang Diuji } & \multicolumn{5}{|c|}{ Valid / Invalid } & \multirow{2}{*}{ Paraf } \\
\hline & & 1 & 2 & 3 & 4 & 5 & \\
\hline 11 & $\begin{array}{l}\text { Nama Uji : Maintenance inventaris } \\
\text { Deskripsi Pengujian: Verifikasi } \\
\text { Maintenance inventaris } \\
\text { Kasus Uji : } \\
\text { Data Inventaris : } \\
\text { Kode Barang : Sistem otomatis } \\
\text { meng-generate kode unik } \\
\text { menggunakan pencarian } \\
\text { Nama Barang : Sistem otomatis } \\
\text { meng-generate kode unik } \\
\text { menggunakan pencarian } \\
\text { Merk : Sistem otomatis meng- } \\
\text { generate kode unik menggunakan } \\
\text { pencarian } \\
\text { Tipe : Sistem otomatis meng- } \\
\text { generate kode unik menggunakan } \\
\text { pencarian } \\
\text { Tanggal Pengadaan : Sistem } \\
\text { otomatis meng-generate kode unik } \\
\text { menggunakan pencarian } \\
\text { Ruang : } \\
\text { Ruang : Sistem otomatis meng- } \\
\text { generate kode unik menggunakan }\end{array}$ & & & & & & \\
\hline
\end{tabular}


DOI: $10.52362 / j m i j a y a k a r t a . v 1 i 1.415$

\begin{tabular}{|l|l|} 
pencarian \\
Unit: Sistem otomatis meng- \\
generate kode unik menggunakan \\
pencarian \\
Kode Inventaris : Sistem otomatis \\
meng-generate kode unik \\
menggunakan pencarian \\
Jumlah : Sistem otomatis meng- \\
generate kode unik menggunakan \\
pencarian
\end{tabular} \mid

\begin{tabular}{|c|c|c|c|c|c|c|c|}
\hline \multirow[b]{2}{*}{ NO } & \multirow{2}{*}{ Kasus Yang Diuji } & \multicolumn{5}{|c|}{ Valid/ Invalid } & \multirow[b]{2}{*}{ Paraf } \\
\hline & & 1 & 2 & 3 & 4 & 5 & \\
\hline & $\begin{array}{l}\text { Ruang Tujuan : } \\
\text { - Ruang : Sistem otomatis meng- } \\
\text { generate kode unik menggunakan } \\
\text { pencarian } \\
\text { - Unit Kerja: Sistem otomatis meng- } \\
\text { generate kode unik menggunakan } \\
\text { pencarian } \\
\text { - Jumlah Inventaris : Sistem otomatis } \\
\text { meng-generate kode unik } \\
\text { menggunakan pencarian } \\
\text { - Keterangan : Sistem otomatis meng- } \\
\text { generate kode unik menggunakan } \\
\text { pencarian } \\
\text { Hasil yang diharapkan : } \\
\text { - Jika berhasil akan menampilkan } \\
\text { konfirmasi 'data barang berhasil } \\
\text { disimpan' dan menampilkan tabel } \\
\text { barang dimana data yang diinput }\end{array}$ & & & & & & \\
\hline
\end{tabular}


DOI: $10.52362 / j m i j a y a k a r t a . v 1 i 1.415$

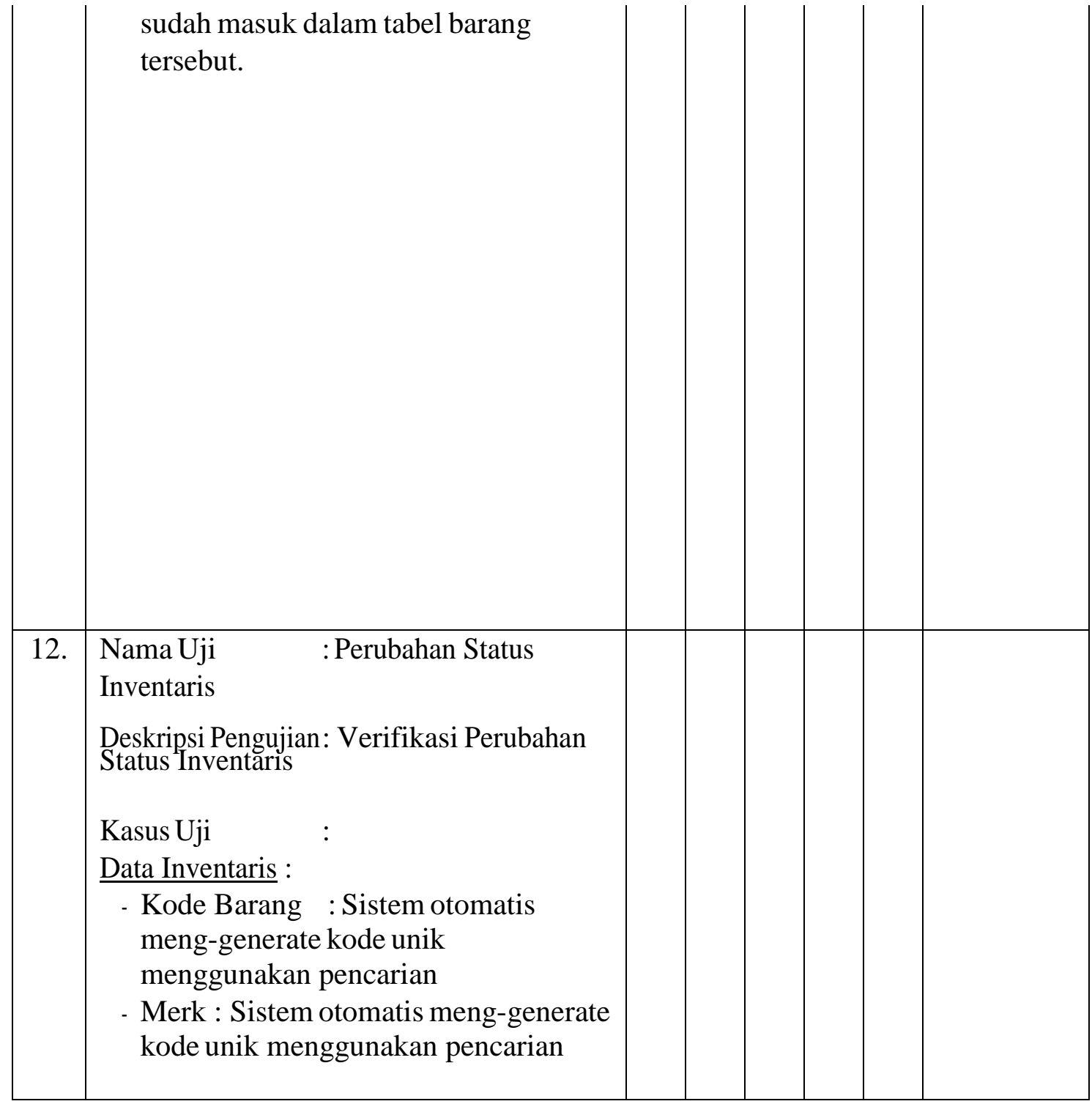

\begin{tabular}{|c|c|c|c|c|c|c|c|}
\hline \multirow{2}{*}{ NO } & Kasus Yang Diuji & \multicolumn{4}{|c|}{ Valid/ Invalid } & \multirow{2}{*}{ Paraf } \\
\cline { 3 - 5 } & 13. & 1 & 2 & 3 & 4 & 5 & \\
\hline $\begin{array}{c}\text { Tipe : Sistem otomatis meng-generate } \\
\text { kode unik menggunakan pencarian } \\
\text { Tanggal Pengadaan : Sistem otomatis }\end{array}$ & & & & & & \\
\hline
\end{tabular}


DOI: 10.52362/jmijayakarta.v1i1.415

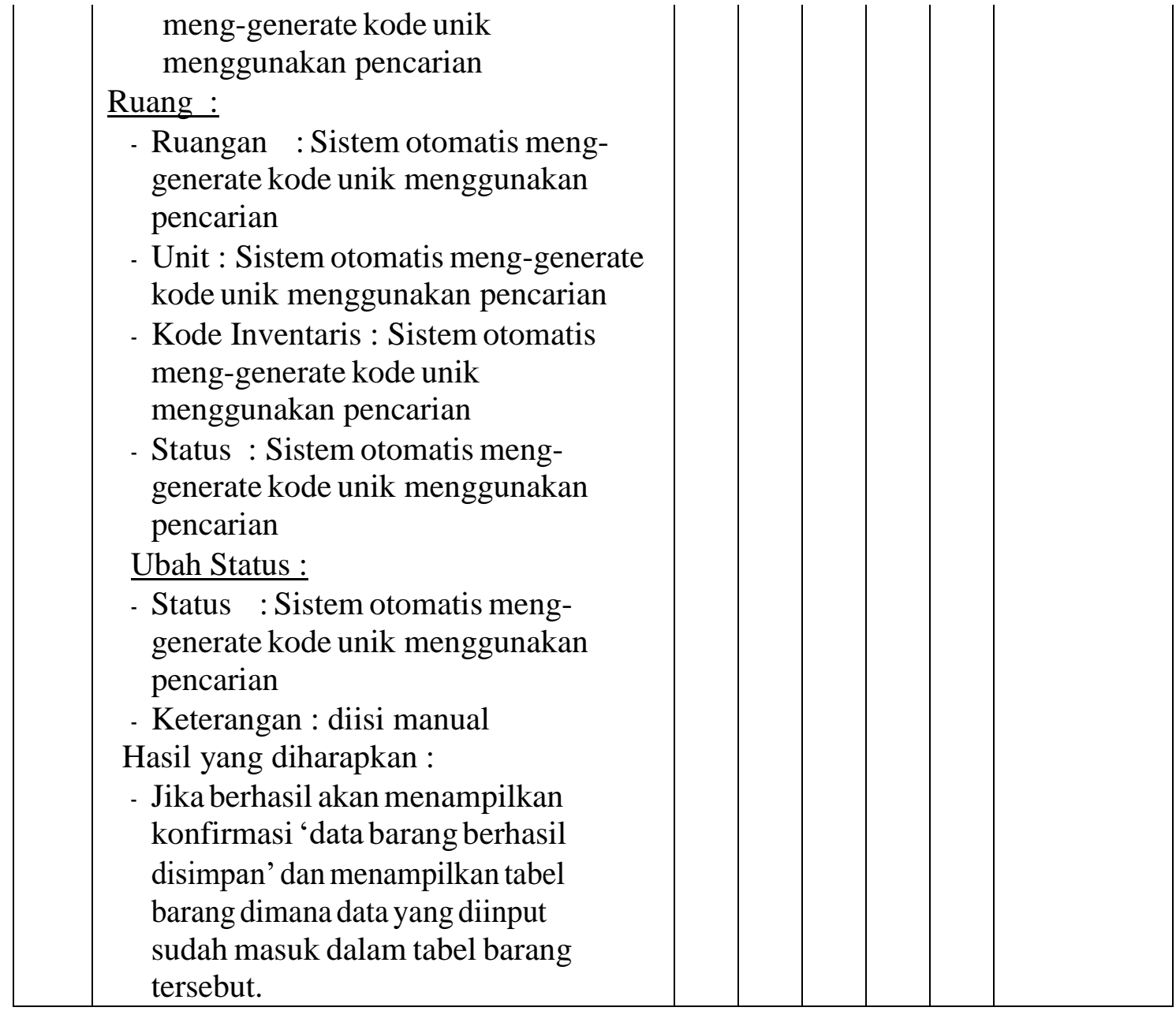

Nama Penguji : SUSANGKA,S.Pd.M.M

Angka 1 = Aplikasi dapat dioperasikan dengan normal

Angka 2 = Aplikasi ada kesulitan saat operasi

Angka 3 = Aplikasi sedikit ada trouble

Angka $4=$ Aplikasi masih banyak error

Angka 5 = Aplikasi tidak bisa dioperasikan sama sekali

Jakarta, ..... Februari 2021

\section{Hasil Pengujian}

UAT 1

Angka 1 = Aplikasi dapat dioperasikan dengan normal

Total $=10: 13=0,76 \%$

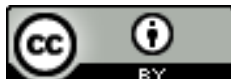

Ciptaan disebarluaskan di bawah Lisensi Creative Commons Atribusi 4.0 Internasional. http://journal.stmikjayakarta.ac.id/index.php/JMIJayakarta 
DOI: 10.52362/jmijayakarta.v1i1.415

Angka 2 = Aplikasi ada kesulitan saat operasi

Total $=1: 13=0.07 \%$

Angka $3=$ Aplikasi sedikit ada trouble

Total $=2: 13=0.15 \%$

Angka $4=$ Aplikasi masih banyak error

Total $=1: 13=0,07 \%$

Angka 5 = Aplikasi tidak bisa dioperasikan sama sekali

Total $=0$

UAT 2

Angka 1 = Aplikasi dapat dioperasikan dengan normal

Total $=11: 13=0,84 \%$

Angka 2 = Aplikasi ada kesulitan saat operasi

Total $=1: 13=0,07 \%$

Angka 3 = Aplikasi sedikit ada trouble

Total $=3: 13=0,15$

Angka 4 = Aplikasi masih banyak error

Total $=0: 13=0$

Angka 5 = Aplikasi tidak bisa dioperasikan sama sekali

Total $=0: 13=0$

Tabel 4.11 hasil UAT 1 dan UAT 2

\begin{tabular}{|l|l|c|c|c|l|}
\hline No & \multicolumn{1}{|c|}{ Kategori Hasil Yang di uji } & $\begin{array}{c}\text { UAT } \\
1\end{array}$ & HASIL & $\begin{array}{c}\text { UAT } \\
2\end{array}$ & HASIL \\
\hline 1 & Aplikasi dapat dioperasikan dengan normal & 10 & $0.76 \%$ & 11 & $0,84 \%$ \\
\hline 2 & Aplikasi ada kesulitan saat operasi & 1 & $0.07 \%$ & 1 & $0.07 \%$ \\
\hline 3 & Aplikasi sedikit ada trouble & 2 & $0.15 \%$ & 2 & $0,15 \%$ \\
\hline 4 & Aplikasi masih banyak error & 1 & $0.07 \%$ & 0 & $0,13 \%$ \\
\hline 5 & Aplikasi tidak bisa dioperasikan sama sekali & 0 & $0.00 \%$ & 0 & $0,00 \%$ \\
\hline
\end{tabular}

$\underline{\text { Rumus Perhitungan Hasil }}$

Total keterangan hasil di bagi dengan total kasus yang di uji

\section{KESIMPULAN}

Bedasarkan observasi penelitian yang di lakukan dengan riset lapangan ,maka dengan ini perancangan sistem informasi inventaris aset berbasis web dengan metode waterfall yang mengunakan use case diagram, class diagram , merupakan data yang struktur, bahwa perancangan ini akan mempermudah pengurus barang dalam melakukan pekerjaannya.

\section{REFERENSI}

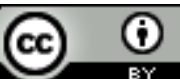

Ciptaan disebarluaskan di bawah Lisensi Creative Commons Atribusi 4.0 Internasional.

http://journal.stmikjayakarta.ac.id/index.php/JMIJayakarta 
DOI: 10.52362/jmijayakarta.v1i1.415

Disusun dan diberi nomor urut berdasarkan urutan kutipan. Penulisan pustaka: nama penulis (tanpa gelar), tahun, judul, penerbit, dan kota penerbit. Berikut adalah contoh penulisan daftar pustak/referensi:

[1] Kusrini, Andi koniyo. (2007). VISUAL BASIC \& MICROSOFT SQL SERVER. CV. andi Offset. https://books.google.co.id/books?id=NaKZXXsJdEC\&pg=PA79\&dq=perancangan+sistem\&hl=id\&sa=X\& ved=2ahUKEwiWppLu69TuAhUESX0KHR4eA0QQ6AEwBHoECAAQAg\#v=onepage\&q=perancangan $\% 20$ sistem $\& \mathrm{f}=$ false

[2] Yeni Kustiyahningsih, \& Devie Rosa Anamisa. (2011). Pemograman Basis Data Berbasis Web Menggunakan $P H P \& M Y S Q L$. GRAHA ILMU.

[3] Rahmat Hidayat. (2011). Cara Praktis Membangun Web Gratis (PT. Elex Media Koputindo (ed.)).

[4] Firmansyah, Y., \& Jamilah, J. (2018). Implementasi Sdlc Waterfall Dalam Pembuatan Game Edukasi Perjuangan Indonesia"Hisotira" Menggunakan Rpg Maker Mv Berbasis Android. Jurnal Khatulistiwa Informatika, 6(2), 178-185. https://doi.org/10.31294/khatulistiwa.v6i2.

[5] Verdi Yasin. (2012). Rekayasa Perangkat Lunak Berorientasi Objek. Mitra Wacana Media.

[6] Badri Zaki dan Syahrizal Dwi Putra (2018) “Aplikasi bengkel online menggunakan global positioning system (gps) berbasis android pada CV. Rumah Otomotif", Journal of Information System, Informatics and Computing, Volume 2 Nomor 2 (2018) p16-25, diterbitkan tanggal 31 Desember 2018). http://journal.stmikjayakarta.ac.id/index.php/jisicom/article/view/64

[7] Anis Rohmadi dan Verdi Yasin (2020) "Desain dan penerapan website tata kelola percetakan pada CV Apicdesign Kreasindo Jakarta dengan metode prototyping", Journal of Information System, Informatics and Computing, Volume 4 Nomor 1 (2020) p70-85, diterbitkan tanggal 22 Juni 2020). http://journal.stmikjayakarta.ac.id/index.php/jisicom/article/view/210

[8] Jajang Murpratomo, Syafiyudin Maulana, Dewi Astria Wiyono, Riska Mahlia, Verdi Yasin (2019) "The Future of software engineering aplikasi penanganan bencana berbasis android", Journal of Information System, Applied, Management, Accounting and Research, Volume 3 Nomor 3 (2019) p33-40, diterbitkan tanggal 13 Agustus 2019. http://journal.stmikjayakarta.ac.id/index.php/jisamar/article/view/104

[9] Wahyuni, S., \& Rifki Khoirudin. (2020). PENGANTAR MANAJEMEN ASET. CV. Nas Media Pustaka. 